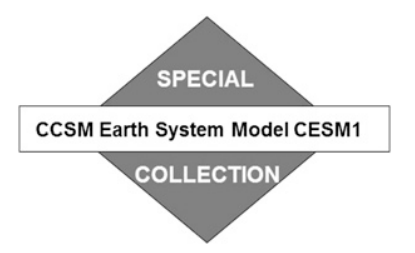

\title{
Greenland Surface Mass Balance as Simulated by the Community Earth System Model. Part II: Twenty-First-Century Changes
}

\author{
MIREN VIZCAÍNO* \\ Department of Geography, University of California, Berkeley, Berkeley, California, and Institute for Marine and Atmospheric
} Research, Utrecht University, Utrecht, Netherlands

WILLIAM H. LIPSCOMB

Group T-3, Los Alamos National Laboratory, Los Alamos, New Mexico

WILLIAM J. SACKS

National Center for Atmospheric Research, Boulder, Colorado

MichiEL VAN DEN BROEKE

Institute for Marine and Atmospheric Research, Utrecht University, Utrecht, Netherlands

(Manuscript received 31 July 2012, in final form 11 June 2013)

\begin{abstract}
This study presents the first twenty-first-century projections of surface mass balance (SMB) changes for the Greenland Ice Sheet (GIS) with the Community Earth System Model (CESM), which includes a new ice sheet component. For glaciated surfaces, CESM includes a sophisticated calculation of energy fluxes, surface albedo, and snowpack hydrology (melt, percolation, refreezing, etc.). To efficiently resolve the high SMB gradients at the ice sheet margins and provide surface forcing at the scale needed by ice sheet models, the SMB is calculated at multiple elevations and interpolated to a finer 5-km ice sheet grid. During a twenty-firstcentury simulation driven by representative concentration pathway 8.5 (RCP8.5) forcing, the SMB decreases from $372 \pm 100 \mathrm{Gt} \mathrm{yr}^{-1}$ in $1980-99$ to $-78 \pm 143 \mathrm{Gt} \mathrm{yr}^{-1}$ in $2080-99$. The $2080-99$ near-surface temperatures over the GIS increase by $4.7 \mathrm{~K}$ (annual mean) with respect to 1980-99, only 1.3 times the global increase $(+3.7 \mathrm{~K})$. Snowfall increases by $18 \%$, while surface melt doubles. The ablation area increases from $9 \%$ of the GIS in $1980-99$ to $28 \%$ in $2080-99$. Over the ablation areas, summer downward longwave radiation and turbulent fluxes increase, while incoming shortwave radiation decreases owing to increased cloud cover. The reduction in GIS-averaged July albedo from 0.78 in 1980-99 to 0.75 in 2080-99 increases the absorbed solar radiation in this month by $12 \%$. Summer warming is strongest in the north and east of Greenland owing to reduced sea ice cover. In the ablation area, summer temperature increases are smaller due to frequent periods of surface melt.
\end{abstract}

\section{Introduction}

The Greenland Ice Sheet (GIS) is the largest ice body in the Northern Hemisphere. It holds a volume of ice

\footnotetext{
* Current affiliation: Department of Geoscience and Remote Sensing, Delft Institute of Technology, Delft, Netherlands.

Corresponding author address: Miren Vizcaíno, Stevinweg 1, 2628 CN Delft, Netherlands.

E-mail: m.vizcaino@tudelft.nl
}

equivalent to $7.3 \mathrm{~m}$ of average global sea level rise (Bamber et al. 2001). Ice sheets gain mass through snowfall and deposition and lose mass through sublimation, basal melt due to geothermal heating, surface melt and subsequent meltwater runoff, basal melt of ice shelves, and iceberg calving. Of the processes that remove mass, the largest contributions come from calving, ocean melt, and surface meltwater runoff (Jacobs et al. 1992; Silva et al. 2006; Ettema et al. 2009; van den Broeke et al. 2009; Lenaerts et al. 2012). In Antarctica there is little runoff due to the extremely cold environment 
(Lenaerts 2012). In Greenland, however, runoff is an important process of mass removal (Ettema et al. 2009). Between 1961 and 1990, accumulation over the GIS was estimated at $\sim 700 \mathrm{Gtyr}^{-1}$, runoff at $\sim 250 \mathrm{Gt} \mathrm{yr}^{-1}$, and ice discharge at $\sim 450 \mathrm{Gt} \mathrm{yr}^{-1}$, under the assumption of the ice sheet being in equilibrium (Ettema et al. 2009; van den Broeke et al. 2009). In recent years runoff has increased more strongly than discharge (Rignot et al. 2011). The Greenland and Antarctic Ice Sheets are currently losing mass (Rignot et al. 2011; Shepherd et al. 2012). For Greenland, roughly half of the current mass loss has been attributed to accelerated ice flow and half to increased surface meltwater runoff (van den Broeke et al. 2009).

Future changes in the surface mass balance (SMB) of the Greenland Ice Sheet are projected either by melt calculations based on temperature index models [socalled positive-degree-day (PDD) models] or by considering the surface energy balance (SEB) of the ice sheet. PDD calculations rely on the empirical relationship between near-surface temperature and melt (Reeh 1991). The parameters used are tuned to present-day observed SMB. PDDs are a useful method when a SEB calculation is not possible, but the parameters used might not be valid for climate regimes different from the reference climate used for tuning (Bougamont et al. 2007). In addition, these parameters are site specific. SEB methods represent a more physically based approach that permits detailed examination of individual processes contributing to the ice sheet energy and mass balance budget.

Projections of changes in the GIS SMB that are based on SEB schemes have mostly been performed with regional climate models (RCMs) (Fettweis et al. 2013; Rae et al. 2012; van Angelen et al. 2013). RCMs are able to resolve important processes related to the small-scale (tens of kilometers) ice sheet orography and to include sophisticated calculations of the surface energy balance, snow hydrology, and albedo evolution. However, RCMs suffer from their dependency on a global climate model that supplies the boundary conditions.

Projections from general circulation models (GCMs) have been performed with PDD methods or simplified SEB schemes. Ohmura et al. (1996) used a short (5 yr) model simulation with the atmospheric model ECHAM4 at relatively high resolution (T106, or $\sim 1.25^{\circ}$ ) to calculate ice sheet SMB from a simple SEB scheme with parameterized albedo (as a linear function of surface temperature) and without refreezing. Thompson and Pollard (1997) used a SEB scheme with a parameterization for refreezing and albedo in their calculations with the model Global Environmental and Ecological Simulation of Interactive Systems (GENESIS) $\left(\sim 3.75^{\circ}\right.$ atmospheric resolution). Wild and Ohmura (2000) used ECHAM4/T106 and a temperature index SMB calculation for their study. Gregory and Huybrechts (2006) used a combination of low- and high-resolution (T106) models and a PDD scheme to calculate melt. The first projections with an ice sheet model (ISM) bidirectionally coupled to an atmosphere-ocean GCM were performed with PDD schemes and through anomaly forcing (Ridley et al. 2005; Vizcaíno et al. 2008; Mikolajewicz et al. 2007). A more recent study with the ECHAM5/Max Planck Institute Ocean Model (MPI-OM) used a surface energy balance calculation with parameterized albedo (Vizcaíno et al. 2010).

Here we present the first projections of the contribution from changes in the SMB of the GIS to twenty-firstcentury sea level rise with version 1.0 of the Community Earth System Model (CESM1.0). In CESM, ice sheet SMB is calculated with an SEB scheme that includes albedo evolution. Meltwater percolation and refreezing within the snowpack are explicitly modeled (Oleson et al. 2010). The SMB is calculated in the land model [Community Land Model (CLM)] at several fixed elevations and then horizontally and vertically interpolated to the higher resolution of the ice sheet model $(5 \mathrm{~km})$. In a companion paper, the model was shown to realistically simulate the present-day SMB of the Greenland Ice Sheet (Vizcaíno et al. 2013).

The paper is organized as follows. The model and simulations setup are described in section 2. In section 3, the global climate changes during the twenty-first century and the local climate change over Greenland are presented. Section 4 presents the simulated changes in the surface mass balance of the GIS. Section 5 summarizes the main results and conclusions.

\section{Method}

The model used here is CESM1.0 (Hurrell et al. 2013), which includes atmosphere, ocean, sea ice, and land components. In addition, the model includes a new ice sheet component. The calculation of the SMB of the Greenland Ice Sheet is done within the land model (CLM) at several prescribed elevation ranges and downscaled to the higher resolution of the ice sheet model $(5 \mathrm{~km})$. The GIS SMB calculation is described in the companion papers by Lipscomb et al. (2013) and Vizcaíno et al. (2013). Here, a brief summary is given.

The calculation of the SMB of glaciated surfaces, including the Greenland Ice Sheet, is done over two surface types, snow and bare ice, according to

$$
\mathrm{SMB}(\text { ice }+ \text { snow })=\mathrm{SNOW}+\mathrm{RAIN}-\mathrm{RU}-\mathrm{SU},
$$

where SNOW is snowfall, RAIN is rainfall, RU is runoff, and SU is sublimation. 
Runoff is calculated as the portion of the available liquid water (ALW) that is not refrozen:

$$
\mathrm{RU}=\mathrm{ALW}-\mathrm{RF}=\mathrm{ME}+\mathrm{RAIN}-\mathrm{RF},
$$

where ME is melt and RF is refreezing. ME is calculated from the sum of surface fluxes (radiative, turbulent, and subsurface heat):

$\mathrm{ME}=\mathrm{SW}_{d}(1-\alpha)+\mathrm{LW}_{d}-\varepsilon \sigma T_{s}^{4}+\mathrm{SHF}+\mathrm{LHF}+\mathrm{GF}$,

where $\mathrm{SW}_{d}$ is downwelling shortwave radiation, $\alpha$ is albedo, $\varepsilon=0.97$ is the emissivity of the snow/ice surface, sigma is the Stefan-Boltzman constant, $T_{s}$ is surface temperature, $\mathrm{LW}_{d}$ is downward longwave radiation, SHF is sensible heat flux, LHF is latent heat flux, and GF is the subsurface heat flux toward the surface.

In the configuration of CESM used for this study, all components are active except the dynamics of the ice sheet model. Two simulations have been performed for this study. The first one corresponds to the period 1850 2005 and has been subject to analysis in a companion paper (Vizcaíno et al. 2013). The period 1980-99 is used as reference for the future climate projections. A second simulation was branched from the first for the period 2005-2100, with forcing according to the representative concentration pathway 8.5 (RCP8.5) high emissions scenario.

For the analysis of climate and surface mass balance changes, the period 2080-99 is chosen and anomalies are shown with respect to the 1980-99 reference period. The topography of the ice sheet in the ice sheet model is prescribed to present-day values (Bamber et al. 2001) for all simulations.

\section{Global and local climate change}

The mean annual global temperature increases by $3.7 \mathrm{~K}$ for $2080-99$ with respect to the reference period 1980-99 (Fig. 1a). The average temperature change north of $60^{\circ} \mathrm{N}$ is $7.9 \mathrm{~K}$, which represents a polar amplification factor of 2.1. The pattern of warming (Fig. 1b) shows the usual feature of higher warming over the continents than over the oceans. Northern high latitudes warm much more strongly, with anomalies of more than $10 \mathrm{~K}$ over the Arctic Ocean. The northernmost landmasses (Canadian Archipelago, northern Alaska, and northern Siberia) warm the most, with warming exceeding $9 \mathrm{~K}$ for the annual mean. Globally, a local minimum of warming occurs over the North Atlantic, associated with a reduced North Atlantic meridional overturning circulation.
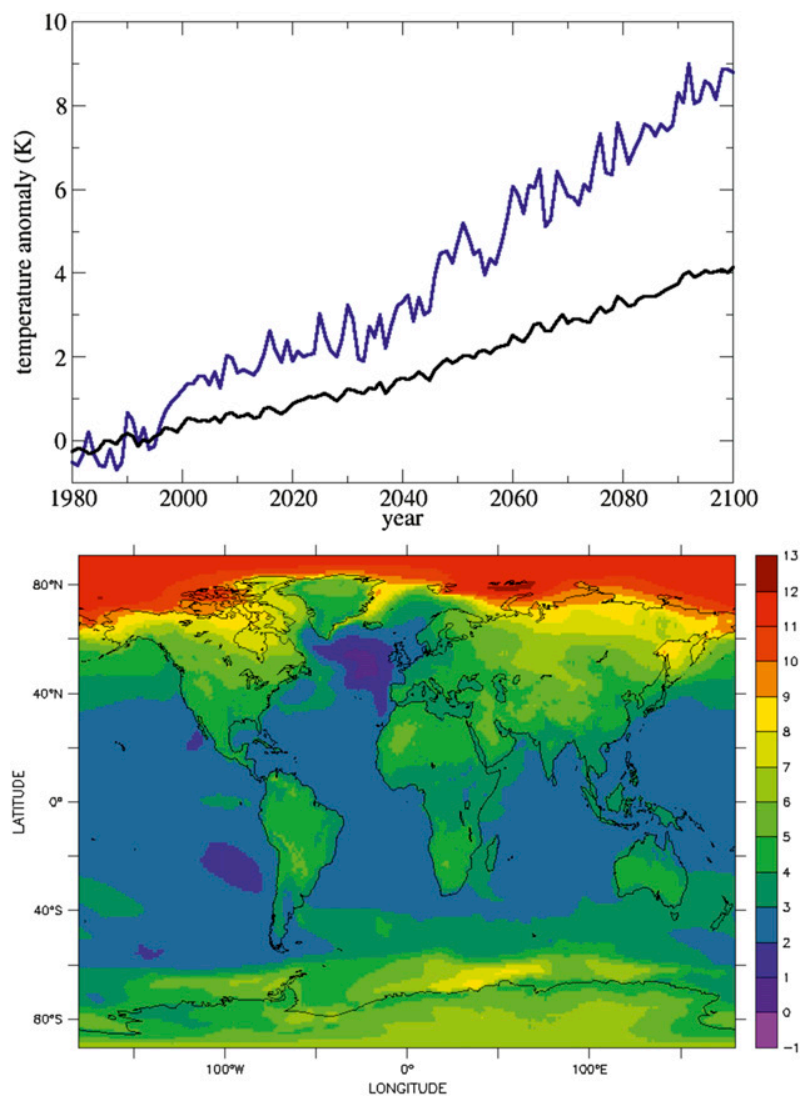

FIG. 1. Global climate change: (top) time series of anomalies of global-mean temperature (black) and annual-mean temperature averaged over the area $60^{\circ}-90^{\circ} \mathrm{N}$ (blue) for the period $1980-2099$ with respect to the mean of the reference period 1980-99. (bottom) Near-surface temperature anomaly 2080-99 minus 1980-99.

The 2080-99 mean increases of annual and summer temperatures over the Greenland Ice Sheet are 4.7 and $4.1 \mathrm{~K}$, respectively. Figure $2 \mathrm{~b}$ shows the summer pattern of warming over Greenland and surroundings by the end of the century. In the ice-free regions, the warming is highest in areas at the north and east $(>5 \mathrm{~K})$ due to reduced sea ice cover at the coast, as well as small areas in the southeast. The lowest increase corresponds to the western part of Greenland (3-4 K). Over the ice sheet, the warming is largest for higher elevations $(>5 \mathrm{~K}$ over $3000 \mathrm{~m}$ ) and decreases toward the margins, where melt occurs with higher frequency, imposing a temperature limit to the surface and reducing the increase in nearsurface air temperature. The minimum increase therefore occurs over the lower part of the western ablation area $(\sim 1-2 \mathrm{~K})$.

\section{Changes in surface energy fluxes over Greenland}

Figure 3 illustrates the changes in summer [JuneAugust (JJA)] surface fluxes over Greenland by 2080-99 

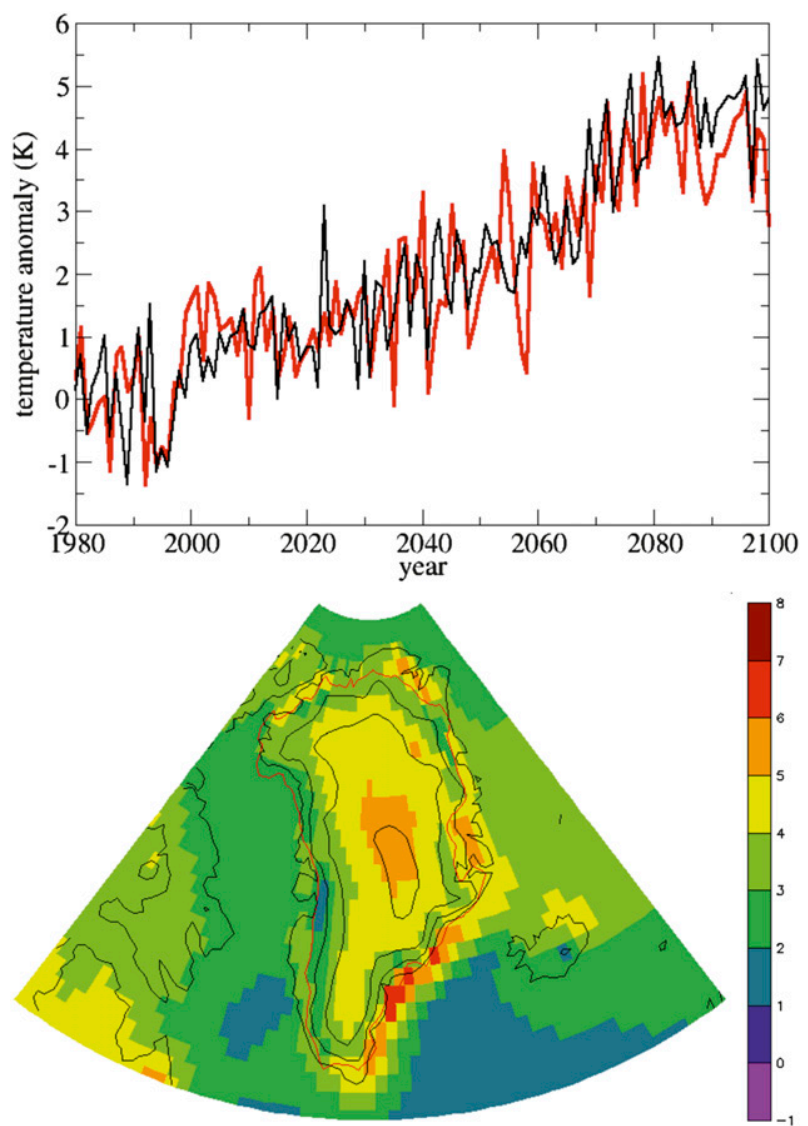

FIG. 2. Temperature change (K) with respect to the period 198099 averaged over the Greenland Ice Sheet: (top) summer (red) and annual (black) time series; (bottom) summer anomalies 2080-99.

with respect to 1980-99. Only statistically significant changes have been plotted. Incoming solar radiation decreases over the ice sheet owing to increased cloud cover, with the highest decrease over the ablation areas $\left(15-65 \mathrm{~W} \mathrm{~m}^{-2}\right)$, particularly in western Greenland $\left(>40 \mathrm{~W} \mathrm{~m}^{-2}\right)$. Albedo changes are significant over the ablation areas, with anomalies between 0.10 and -0.05 , and the highest interior, where it slightly increases $(\sim 0.02)$ due to increased snowfall. Incoming longwave radiation increases over the whole ice sheet. Over the ablation zones, the magnitude of the change $\left(5-15 \mathrm{~W} \mathrm{~m}^{-2}\right.$ over most of the areas and $>15 \mathrm{~W} \mathrm{~m}^{-2}$ over the western Greenland margin) is smaller than for the incoming solar radiation. The effects of increased incoming longwave radiation and reduced albedo offset the effect of reduced incoming solar radiation, which results in net radiation increase over the ice sheet. Over most of the ablation areas, changes are $15-25 \mathrm{~W} \mathrm{~m}^{-2}$. Turbulent flux anomalies are positive over the ablation areas, with similar contributions $\left(5-15 \mathrm{~W} \mathrm{~m}^{-2}\right)$ from the latent and sensible fluxes. Latent heat anomalies are negative over the interior of the ice sheet.

\section{Changes in surface mass balance}

The net SMB decreases from $372 \pm 100 \mathrm{Gt} \mathrm{yr}^{-1}$ in $1980-99$ to $-78 \pm 143 \mathrm{Gt} \mathrm{yr}^{-1}$ in 2080-99 (Table 1). Both precipitation and melt increase. Precipitation increases by $35 \%$, with a substantial contribution from increased rainfall $\left(+174 \mathrm{Gt} \mathrm{yr}^{-1}\right)$. When related to the GIS annual temperature change, this increase in precipitation corresponds to $7.4 \% \mathrm{~K}^{-1}$, higher than the rates of $\sim 5 \% \mathrm{~K}^{-1}$ from Rae et al. (2012) and Gregory and Huybrechts (2006). Snowfall increases by $18 \%$. The difference between melt and runoff becomes smaller with time (Fig. 4). Within two years from the last decade of the twenty-first century, runoff actually exceeds melt, a situation that is unrealistic and is caused by overestimation of rainfall and underestimation of refreezing in the model. These biases will be discussed below. Rainfall increases with time, with an almost threefold increase by 2080-99. The trend line of SMB crosses zero in year 2094.

Linear fits relating the change in GIS SMB to changes in global mean or GIS mean annual temperature with respect to 1980-99 values give sensitivities of -107 and $-79 \mathrm{Gt} \mathrm{yr}^{-1} \mathrm{~K}^{-1}$, respectively. If these linear functions are used, the temperature rise with respect to 1980-99 required for the SMB to become negative is $3.6 \mathrm{~K}$ for the global mean and $4.7 \mathrm{~K}$ for the GIS mean. Negative SMB has been suggested as a threshold for complete elimination of the GIS (Gregory and Huybrechts 2006). The range of values found by Gregory and Huybrechts (2006) for the GIS annual temperature increase with respect to preindustrial is $3.2-6.5 \mathrm{~K}$, while Robinson et al. (2012) suggest $2.0-3.5 \mathrm{~K}$.

Figure 5 shows the mean SMB at the ice sheet grid resolution $(5 \mathrm{~km})$ for the periods $1980-99$ and 2080-99. The first map is similar to the map for 1960-2005, which is discussed in Vizcaíno et al. (2013). The ablation area increases from $9 \%$ of the ice sheet in $1980-99$ to $28 \%$ of the ice sheet in 2080-99. The width of the ablation area increases the most along the western, northern, and northeastern margins. The equilibrium line altitude increases by $\sim 500 \mathrm{~m}$ on average, with a maximum increase of almost $1000 \mathrm{~m}$ in the northeast. In the east and southeast, where previously the ablation areas had a width smaller than the model resolution $(5 \mathrm{~km})$, the $2080-99$ equilibrium line is simulated at approximately $1000 \mathrm{~m}$ for most of the eastern part and between 1000 and $2000 \mathrm{~m}$ over a minor part of the southeastern margin. Above $2000 \mathrm{~m}$, the SMB slightly increases.

\section{a. Changes in precipitation}

Precipitation rates increase by $303 \mathrm{Gt} \mathrm{yr}^{-1}$ (Table 1 ). More than half of this increase (57\%) is due to rainfall. However, as described in the companion paper (Vizcaíno 

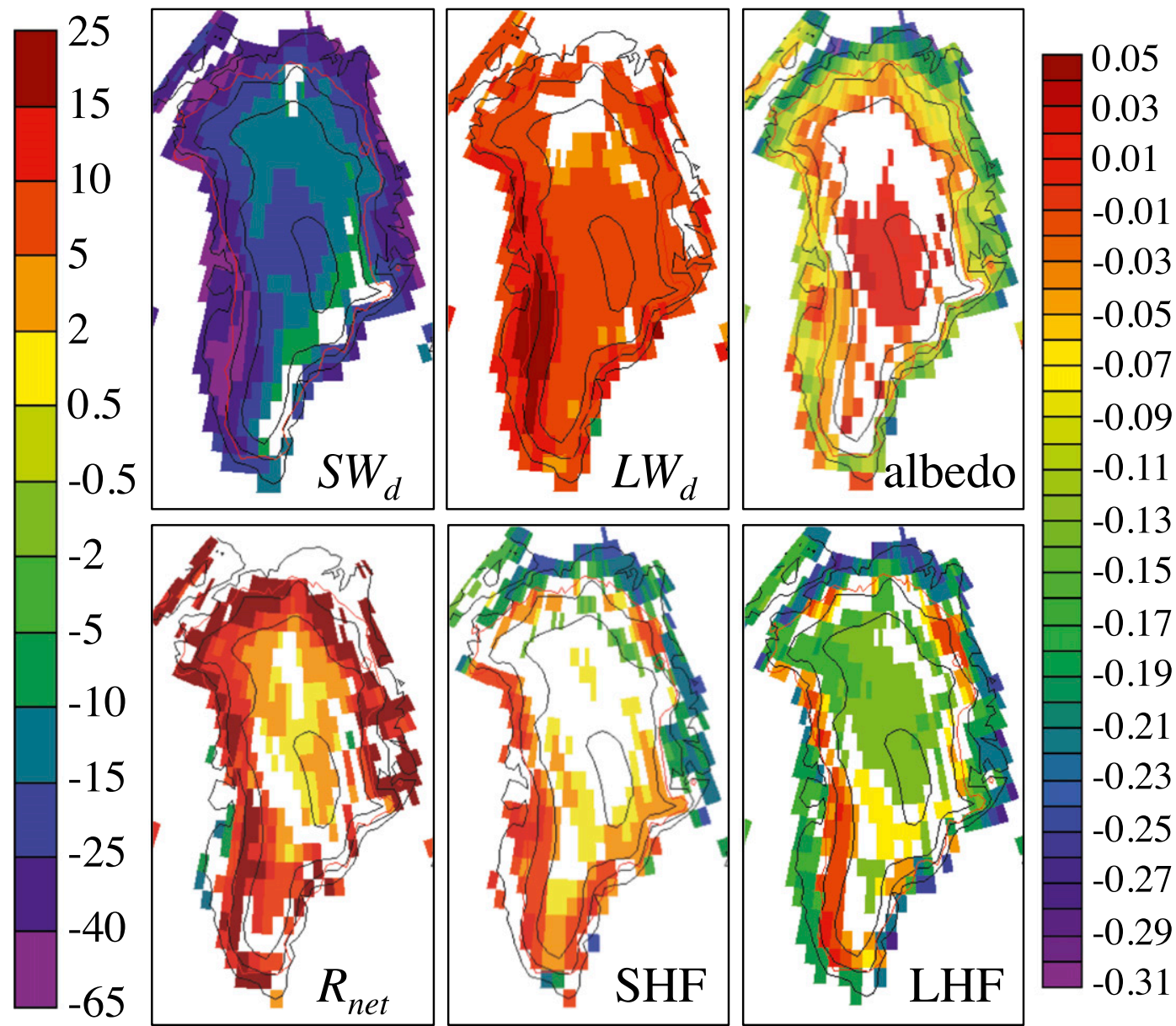

FIG. 3. Summer 2080-99 anomalies of surface fluxes $\left(\mathrm{W} \mathrm{m}^{-2}\right)$ and albedo (unitless) with respect to 1980-99 values: downward shortwave and longwave radiation $\left(\mathrm{SW}_{d}, \mathrm{LW}_{d}\right)$, surface albedo, net radiation $\left(R_{\text {net }}\right)$, and sensible and latent heat fluxes (SHF, LHF). Only statistically significant anomalies are plotted. The left color bar corresponds to surface fluxes, and the right color bar to albedo.

et al. 2013), CESM overestimates rainfall in the current climate, and it is particularly unrealistic in simulating rainfall events in the cold interior of the Greenland Ice Sheet, where near-surface temperatures are well below the freezing point, even in the warmest days of the summer. The projected increase in rainfall is likely to be excessive in connection with this bias. Biases in the simulation of rainfall affect several components of the surface energy and mass balance budgets. First, snowfall contributes to mass gain of the ice sheet, while only the part of rainfall that refreezes contributes to mass gain. Second, the partition between rainfall and snowfall affects surface albedo since snowfall events increase it, while rainfall events decrease it [these effects have been quantified in Box et al. (2012) with the Modèle Atmosphérique Régional (MAR) and satellite data]. Surface albedo, in turn, modifies the energy budget directly through modification of absorbed solar radiation and indirectly via changes in near-surface temperature, melt rates, and water vapor fluxes. Finally, rainfall rates impact the amount of refreezing and therefore the energy budget of the snowpack, which in turn conditions refreezing.

As a result of the higher atmospheric temperatures, the rain fraction increases from $15 \%$ to $26 \%$ (Table 1 ). Snowfall rates increase between 50 and $200 \mathrm{~kg} \mathrm{~m}^{-2} \mathrm{yr}^{-1}$ over most of the ice sheet but decrease along the margins of the southern half, where a larger fraction of precipitation now falls as rain (Fig. 6). Absolute values of rainfall increase the most $\left(>200 \mathrm{~kg} \mathrm{~m}^{-2} \mathrm{yr}^{-1}\right)$ along the western and southern margins.

\section{b. Changes in melt and runoff}

By the end of the twenty-first century, melt increases by $215 \%$ or $634 \mathrm{Gt} \mathrm{yr}^{-1}$ (Table 1). The melt area, defined as the sum of grid cells with a climatological mean of more than $1 \mathrm{~kg} \mathrm{~m}^{-2} \mathrm{yr}^{-1}$, increases from $77 \%$ of the 
TABLE 1. Change in different terms of the surface mass balance (SMB) $\left(\mathrm{Gt} \mathrm{yr}^{-1}\right)$ between 1980-99 and 2080-99. The mean and the standard deviation, the latter in parentheses, are given. The relationship between these terms is given by $\operatorname{SMB}($ ice + snow) $=$ $\mathrm{SNOW}+\mathrm{RAIN}-\mathrm{RU}-\mathrm{SU}$ and $\mathrm{RU}=\mathrm{ALW}-\mathrm{RF}=\mathrm{ME}+$ RAIN - RF.

\begin{tabular}{lccc}
\hline \hline \multicolumn{1}{c}{ SMB term } & $1980-99$ & $2080-99$ & $\begin{array}{c}\text { Anomaly 2080-99 } \\
\text { minus 1980-99 } \\
\text { (ratio) }\end{array}$ \\
\hline SMB (ice) & $372(100)$ & $-78(143)$ & $-450(-121 \%)$ \\
SNOW & $728(59)$ & $857(47)$ & $+129(+18 \%)$ \\
RAIN & $127(19)$ & $301(43)$ & $+174(+237 \%)$ \\
Precipitation & $855(70)$ & $1158(74)$ & $+303(+35 \%)$ \\
Runoff & $438(98)$ & $1168(168)$ & $+730(+266 \%)$ \\
Melt (only snow) & $442(75)$ & $689(68)$ & $+247(+156 \%)$ \\
Melt (snow + ice) & $552(119)$ & $1186(155)$ & $+634(+215 \%)$ \\
Refreezing & $240(25)$ & $318(25)$ & $+78(+33 \%)$ \\
Sublimation & $54(3)$ & $60(4)$ & $+6(+11 \%)$ \\
\hline
\end{tabular}

total area to $100 \%$ (Fig. 7). The largest increases $\left(>2000 \mathrm{~kg} \mathrm{~m}^{-2} \mathrm{yr}^{-1}\right)$ take place in the southern margin. Above $2000 \mathrm{~m}$, simulated melt increases by more than $300 \mathrm{~kg} \mathrm{~m}^{-2} \mathrm{yr}^{-1}$ in the southern third of the ice sheet.

The sum of the melt and rain anomalies gives a total increase in the available liquid water of $808 \mathrm{Gt} \mathrm{yr}^{-1}$ (Table 1). However, refreezing increases only slightly $\left(78 \mathrm{Gt} \mathrm{yr}^{-1}\right)$. The ratio of refreezing to available liquid water drops from $35 \%$ in $1980-99$ to $21 \%$ in $2080-99$. In simulations with the regional model, Regional Atmospheric Climate Model version 2 (RACMO2), the
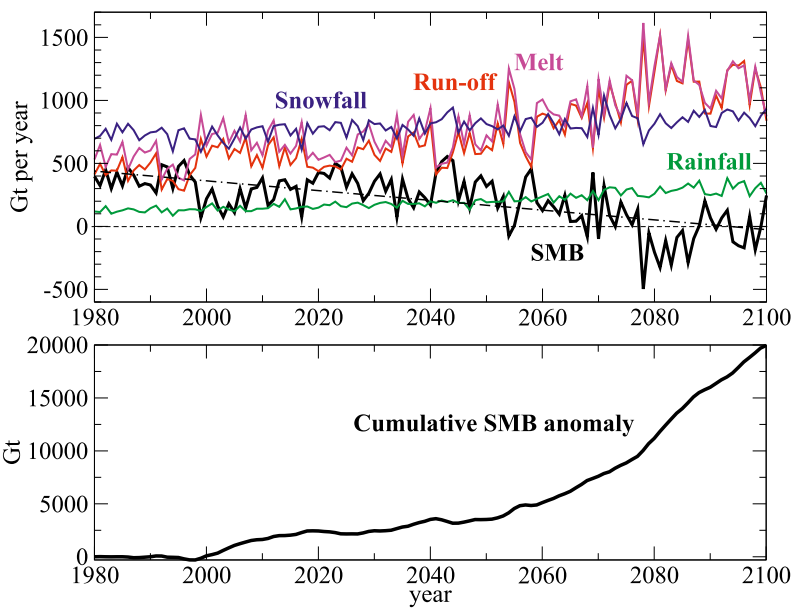

FIG. 4. (top) Time evolution of integrated terms of the surface mass balance (SMB): total SMB (black), snowfall (blue), rain (green), melt (magenta), and runoff (red). The dashed black line indicate SMB trend. Units are $\mathrm{Gt} \mathrm{yr}^{-1}$. (bottom) Cumulative SMB anomaly with respect to $1980-99$ (Gt).

refreezing ratio drops from $38 \%$ in $1992-2011$ to $29 \%$ in 2079-98 under RCP4.5 (van Angelen et al. 2013).

The decrease in the refreezing ratio is due to three processes. The first is the warming of the snow layers owing to heat released during refreezing and to warming of the near-surface atmosphere (Fig. 2). The two remaining processes are related to model constraints and are not physically based. First, in CESM1.0 the thickness
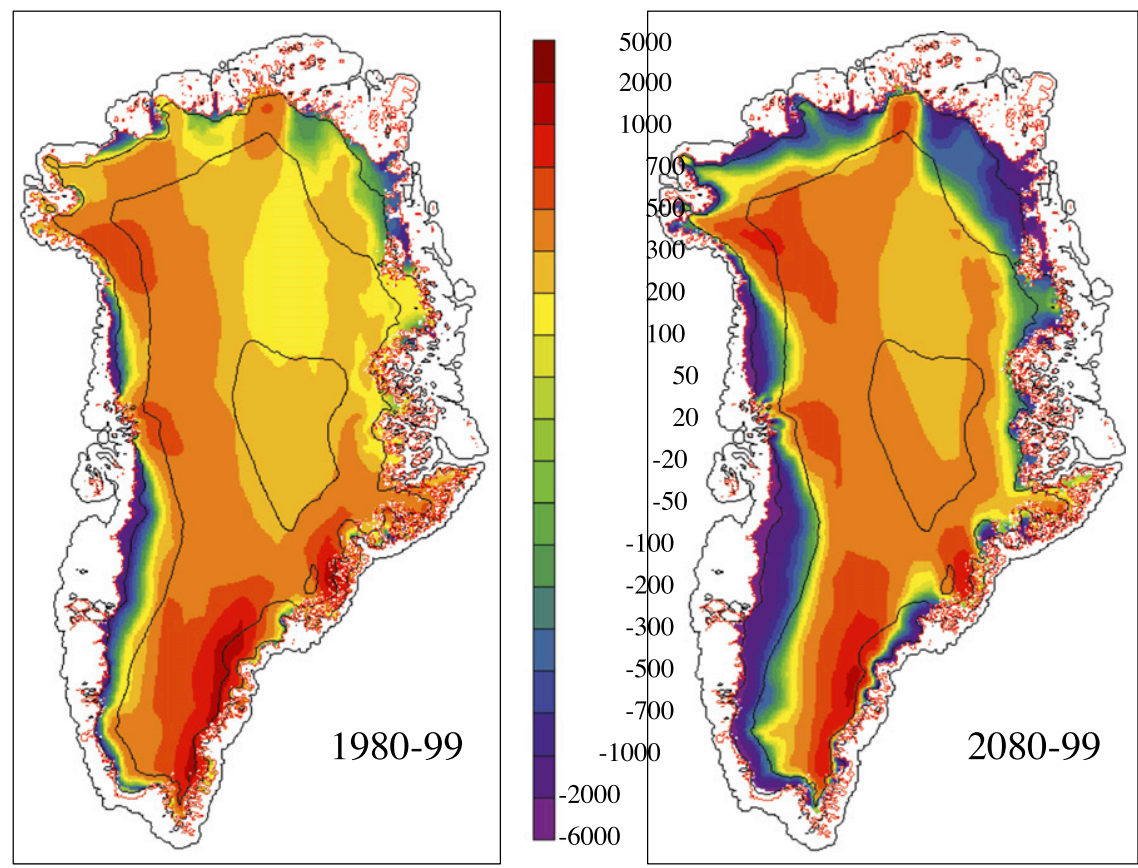

FIG. 5. Mean SMB $\left(\mathrm{kg} \mathrm{m}^{-2} \mathrm{yr}^{-1}\right)$ at 5-km resolution for the periods (left) 1980-99 and (right) 2080-99: contours are plotted every $1000 \mathrm{~m}$. 


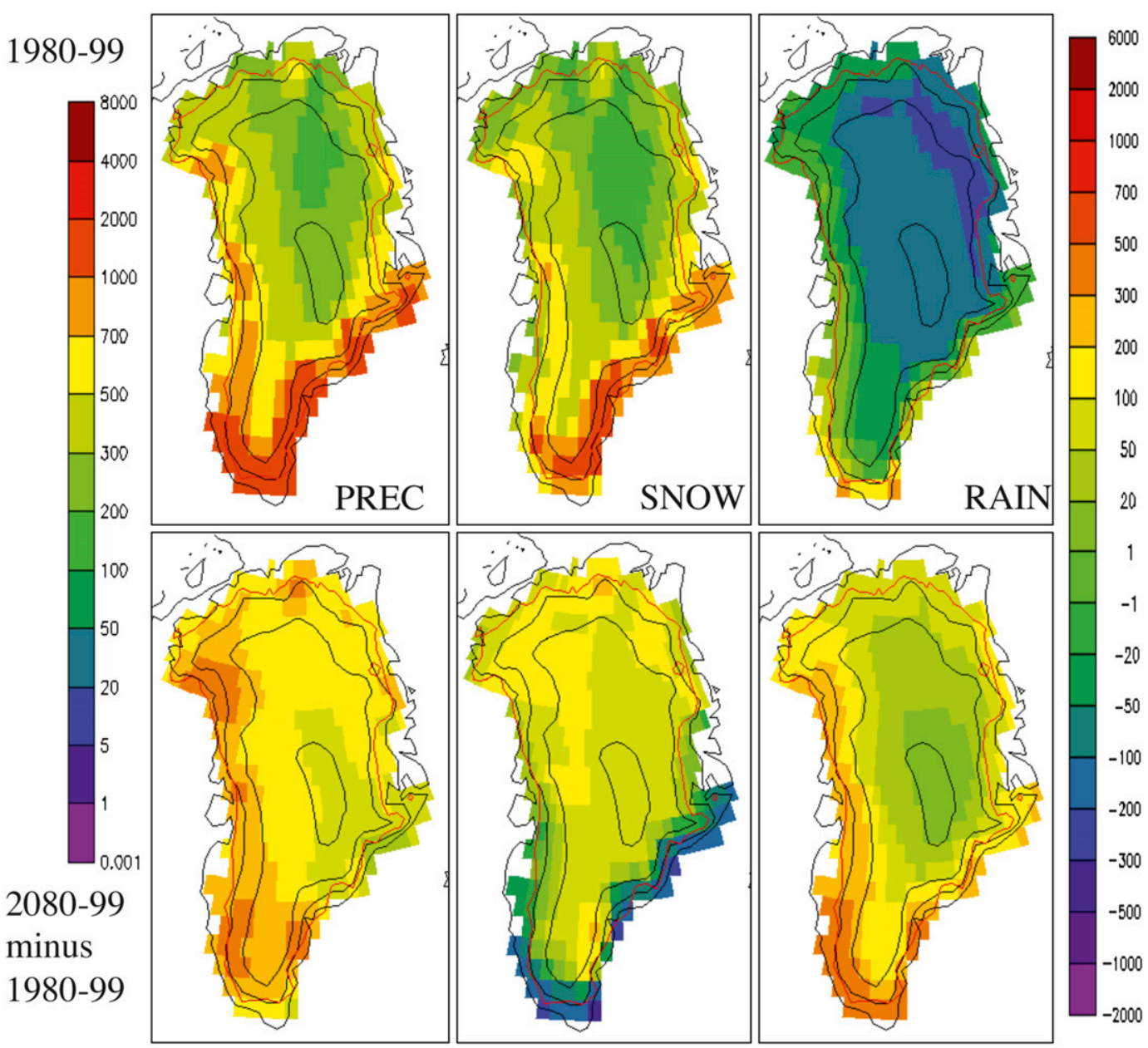

FIG. 6. Spatial pattern of (left) mean precipitation, (middle) snowfall, and (right) rainfall ( $\mathrm{kg} \mathrm{m}^{-2} \mathrm{yr}^{-1}$ ) in the (top) reference climate 1980-99 (left color bar) and (bottom) anomalies of 2080-99 with respect to 1980-99 components (right color bar).

of the snowpack is limited to a maximum $H_{\max }=1 \mathrm{~m}$ liquid water equivalent. This imposes a tight constraint on the refreezing capacity of the snowpack. Second, rainfall over the accumulation zone at times when the thickness equals $H_{\max }$ does not refreeze but runs off. The overestimation of rainfall over the interior of the ice sheet amplifies this effect.

Absolute values of refreezing decrease at most low elevations and increase in the interior (Fig. 7). The total runoff increases by $730 \mathrm{Gt} \mathrm{yr}^{-1}$, even more than melt. The spatial distribution of runoff anomalies is similar to that of melt.

\section{c. Changes in surface albedo}

Surface radiation represents the largest contribution to the energy budget during melt (van den Broeke 2008 a,b). Surface albedo is highly variable over the ice sheet (van Angelen et al. 2012; Box et al. 2012). Typical measured values of albedo over the Greenland Ice Sheet are $\sim 0.80$ for dry snow, $\sim 0.70$ for wet snow, and $\sim 0.50$ for bare ice. Impurities can further reduce the latter value, for instance in the "dark zone" in the western part of the ice sheet (Wientjes and Oerlemans 2010). Some of the processes driving changes in albedo are snowfall and rainfall events, snow temperature, the occurrence of melt, and exposure of bare ice. These changes have a large impact on the local climate and the amount of energy that is available for melt (Box et al. 2012). Part I of this study (Vizcaíno et al. 2013) examines the simulated present-day climatological GIS albedo, seasonal evolution, and impacts on the energy balance. Here we will examine the modeled changes in surface albedo by the end of the twenty-first century.

The modeled mean July albedo over the ice sheet decreases from 0.78 during $1980-99$ to 0.75 in $2080-99$ (Fig. 8), increasing the absorbed solar radiation in this 


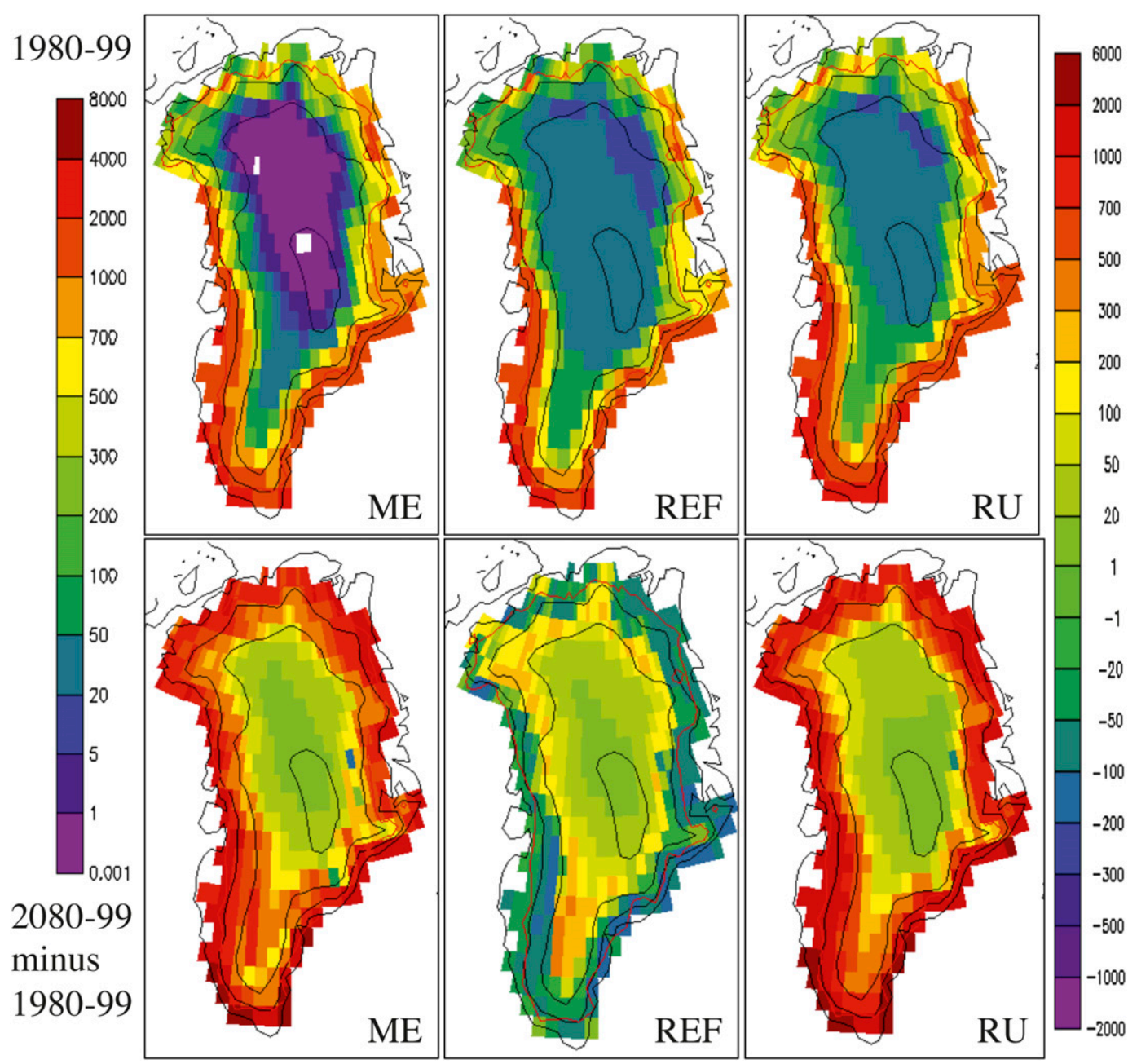

FIG. 7. Spatial pattern of (left) mean surface melt, (middle) refreezing, and (right) runoff ( $\mathrm{kg} \mathrm{m}^{-2} \mathrm{yr}^{-1}$ ) in the (top) reference climate 1980-99 (left color bar) and (bottom) anomalies of 2080-99 with respect to 1980-99 (right color bar).

month by $12 \%$. The surface albedo drops over most of the margins, reaching values close to 0.50 below $1000 \mathrm{~m}$, with the largest reduction in the north and northeast. In the northeast and southwest the albedo drops close to bare ice values in areas above $1000 \mathrm{~m}$. Along the northwestern margin, where the topographic gradient is strong, there are no changes in the albedo, which does not drop below the values typical for wet snow $(\sim 0.7)$. For heights over $2000 \mathrm{~m}$ in the northern half of the ice sheet, the albedo does not change substantially and even increases in mid-Greenland due to increased snowfall events. Over the higher elevations of the southern half of the ice sheet, the area with values typical of wet snow $(\sim 0.7)$ increases.

The high increase in rainfall in CESM is likely to have a substantial impact in the simulated albedo (Box et al. 2012). The role of rainfall on albedo variability and trends, along with the relative role of other factors, will be examined in future studies.

\section{d. Changes in seasonality}

Figure 9 shows the mean daily values of melt and refreezing averaged over the whole ice sheet for the periods 1980-99 and 2080-99. The curves for 1980-99 are similar to those for 1960-2005, discussed in Vizcaíno et al. (2013). The date of seasonal melt onset does not change by the end of the century, being still mid April. However, bare ice is exposed approximately 15 days earlier in 2080-99 in early June. For reference, recent trends in the date of bare ice exposure indicate higher anomalies than these projected changes in the mean climate (Fettweis et al. 2008; Mote 2007; Tedesco 2007; Tedesco et al. 2011). Snowmelt peaks in early June in 1980-99 but continues increasing one more week in 2080-99 before declining. After mid-September, very little snowmelt occurs during both periods. Ice melt peaks in early August in 1980-99 and 5 days later in 

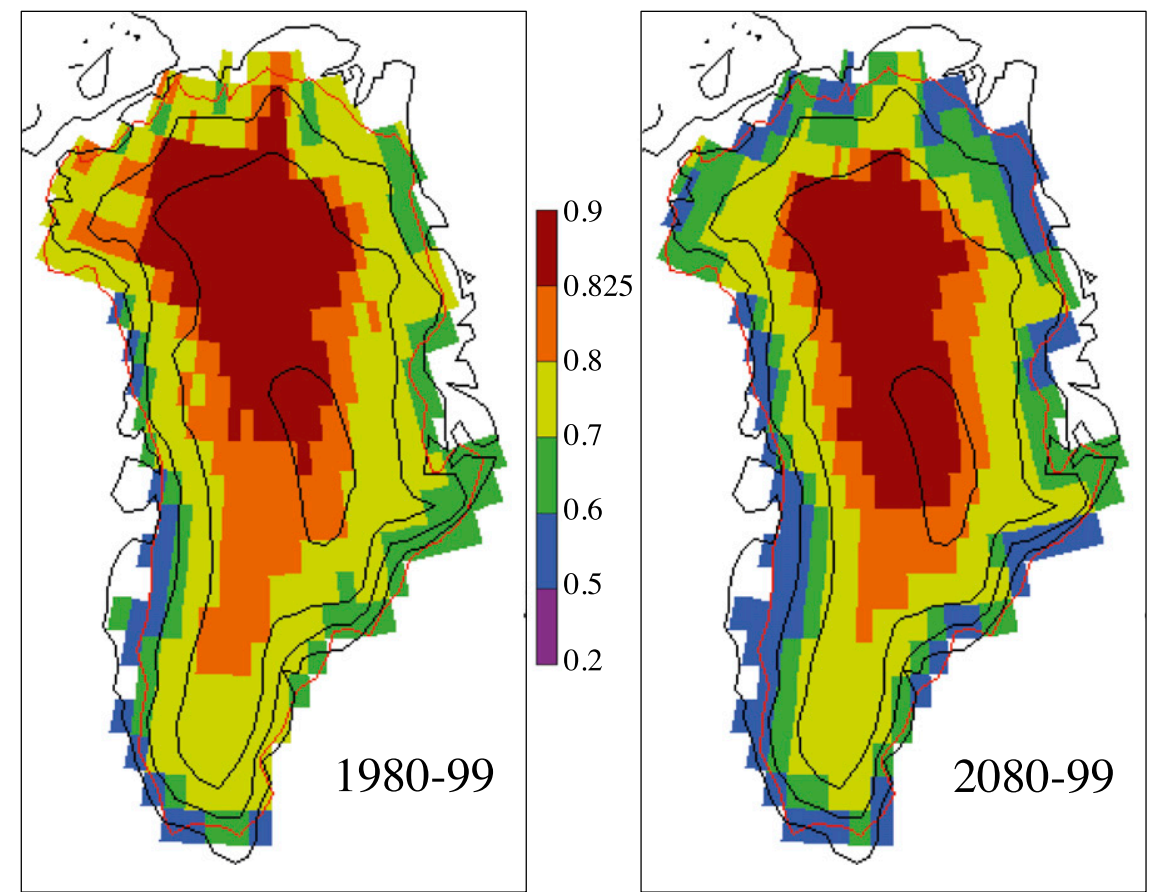

FIG. 8. Mean July albedo of the periods (left) 1980-99 and (right) 2080-99. Only grid cells with glacier coverage of more than $1 \%$ have been plotted. The albedo values correspond only to the glacier fraction of each cell. Typical values are $\sim 0.80$ for dry snow, $\sim 0.70$ for wet snow, and $\sim 0.50$ for bare ice.

2080-99. Ice melts approximately 15 days longer at the end of the melt season in September. This, together with the earlier exposure of bare ice, represents a lengthening of the period of bare ice melt by one month.

The number of melt days (considering a melt threshold of $1 \mathrm{~kg} \mathrm{~m}^{-2}$ day $^{-1}$ ) increases over $89 \%$ of the ice sheet (Fig. 10). The average increase is 57 days. The highest increases ( $~ 90$ days) take place in the southern interior and between 1000 and $2000 \mathrm{~m}$ in the north. Along the southern margin of the ice sheet, the length of the melt season increases to more than 200 days, up to a maximum of 273 days in one of the southernmost grid points.

The timing and amount of refreezing do not change much by $2080-99$. The peak of refreezing is in early June in both periods. Also, some refreezing takes place after melt has ceased in late September owing to refreezing of small amounts of rain.

Sublimation peaks earlier in 2080-99, in late June (not shown); the peak for 1980-99 takes place in early July. Summer sublimation is reduced, while sublimation rates increase at other times of the year.

\section{e. Changes in $S M B$ variability}

Variability of the SMB increases with the warming over the ice sheet. The SMB standard deviation increases from $100 \mathrm{Gt} \mathrm{yr}^{-1}$ in $1980-99$ to $143 \mathrm{Gt} \mathrm{yr}^{-1}$ in $2080-99$
(Table 1). This increase in variability is related to increased melt rates and the impact of melt on the surface climate via the albedo feedback.

\section{Summary and conclusions}

This paper presents the first projection of the twentyfirst-century surface mass balance (SMB) of the Greenland

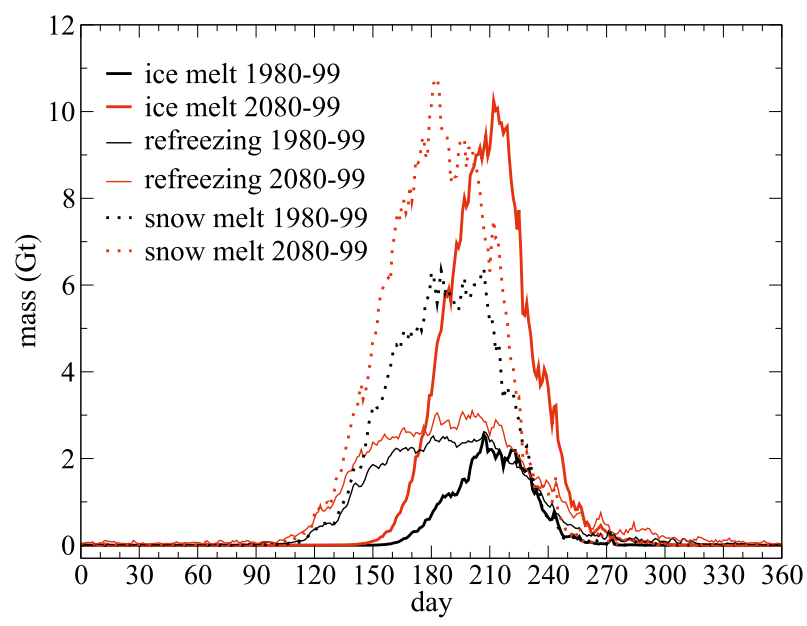

FIG. 9. Daily values of simulated snowmelt, ice melt, and refreezing (Gt) averaged over the years 1980-99 (black) and 2080-99 (red). 

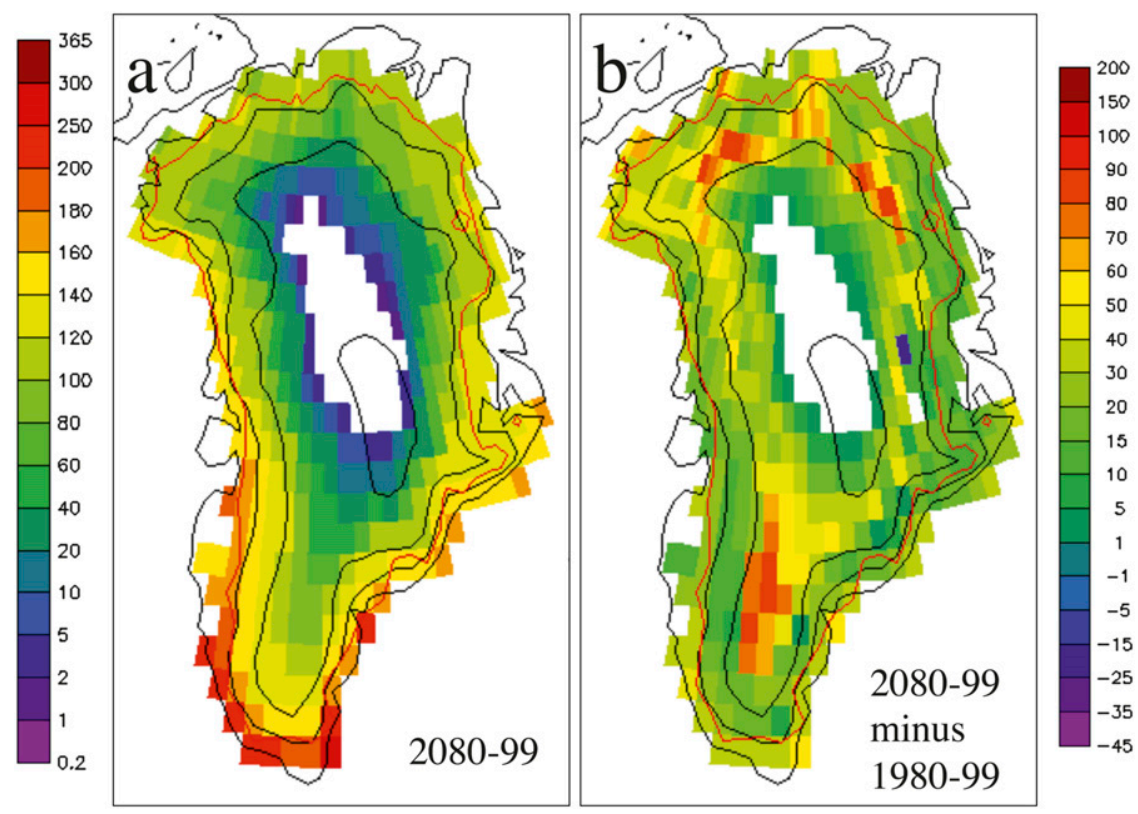

FIG. 10. (a) Mean number of melt days during 2080-99 and (b) anomalies with respect to 1980-99; the melt threshold is $1 \mathrm{~kg} \mathrm{~m}^{-2}$ day $^{-1}$.

Ice Sheet with the Community Earth System Model (CESM). This projection is forced with the Coupled Model Intercomparison Project phase 5 (CMIP5) scenario RCP8.5. Version 1.0 of CESM includes a new ice sheet component and calculates the ice sheet SMB in the land component with an energy balance scheme at several fixed elevation classes. The SMB is downscaled to 5-km resolution. In Part I of this study (Vizcaíno et al. 2013) the model is evaluated against data from in situ and satellite observations and from the output of the regional climate model (RACMO2) (van Angelen et al. 2012).

CESM1.0 projects a global increase of the annualmean temperature of $3.7 \mathrm{~K}$ by $2080-99$. Over the GIS, the annual and summer anomalies are 4.7 and $4.1 \mathrm{~K}$, respectively. From the downward radiation changes over the ablation areas, shortwave fluxes decrease morein response to increased cloud cover-than longwave fluxes increase in response to changes in cloud cover, water vapor, and atmospheric temperature. However, reduced surface albedo causes a net increase in radiation, which becomes the major source for increased surface energy input over the ablation and percolation areas, followed by roughly equal contributions of sensible and latent heat fluxes.

The net SMB decreases from $372 \pm 100 \mathrm{Gt} \mathrm{yr}^{-1}$ in $1980-99$ to $-78 \pm 143 \mathrm{Gt} \mathrm{yr}^{-1}$ in $2080-99$. This is equivalent to a contribution from the GIS SMB to (global mean) sea level rise of $5.5 \mathrm{~cm}$ by 2100 with respect to the 1980-99 level. For reference, the contribution from the
GIS SMB by 2000 with respect to the $1880-99$ level is $1.0 \mathrm{~cm}$ (Vizcaíno et al. 2013), much lower than the estimate of $3.0 \mathrm{~cm}$ for the period 1865-1990 from Zuo and Oerlemans (1997). The surface mass balance calculations have been done at the present-day observed topography of the ice sheet (Bamber et al. 2001), and therefore neither the effects of changes in ice dynamics nor interactions between surface mass balance and topography (e.g., SMB height feedbacks) have been included here. These effects are included in the study of Lipscomb et al. (2013), where an ice sheet model is forced with CESM SMB for the period 1850-2100.

Precipitation rates increase by $18 \%$ but surface melting and runoff increase more $(215 \%$ and $266 \%$, respectively). The ratio of refreezing to total available liquid water (i.e., the sum of melt and rainfall) decreases from $35 \%-21 \%$. The ablation area increases most along the western, northern, and northeastern margins, with an average lifting of the equilibrium line of approximately $500 \mathrm{~m}$. CESM1.0 results up to 2100 are similar to results from the state-of-the-art regional climate models MAR (Fettweis et al. 2013; Rae et al. 2012) and RACMO2 (van Angelen et al. 2013). MAR projects a GIS SMB contribution to sea level rise of $4 \pm 2 \mathrm{~cm}$ for RCP4.5 and $9 \pm 4 \mathrm{~cm}$ for RCP8.5 (Fettweis et al. 2013). RACMO2 projects a sea level rise of $7 \pm 1 \mathrm{~cm}$ for RCP4.5. Neither MAR nor RACMO2 projections account for the melt-height feedback.

Two major limitations of our projections of GIS SMB have been identified. The first one is the simulation of 
rainfall events at temperatures well below freezing in the interior of the ice sheet. Biases in rainfall impact the energy and mass balance budgets in various ways. Rainfall, as opposed to snowfall, only contributes as a mass source if it refreezes. The refreezing of rainfall increases temperatures in the snowpack, limiting subsequent refreezing. Lastly, rainfall events reduce surface albedo (Box et al. 2012). The second major limitation is the limited thickness of the snowpack in the current model configuration. This limits the amount of refreezing in the percolation and ablation areas, potentially biasing the transient response of the GIS to climate changes. Additional work is needed to explore the sensitivity of the steady-state and transient SMB to the choice of maximum snowpack thickness.

The results presented here and in Part I of this study for the preindustrial and historical (1850-2005) periods (Vizcaíno et al. 2013) represent the first successful attempt to generate the SMB of the Greenland Ice Sheet with a global climate model. CESM is a promising modeling tool for the simulation and understanding of ice sheet SMB and its impact on local and global climate.

Acknowledgments. M. Vizcaíno was funded via NSF Grant ATM-0917755 to UC Berkeley and a Marie Curie International Incoming Fellowship within the Seventh European Community Framework Programme (FP7PEOPLE-2010-IIF-272956). Support for WHL was provided by the Scientific Discovery through Advanced Computing (SciDAC) project funded by the U.S. Department of Energy, Office of Science, Advanced Scientific Computing Research and Biological and Environmental Research (BER). The Los Alamos National Laboratory is operated by the DOE National Nuclear Security Administration under Contract DE-AC52-06NA25396. WJS was supported by the National Science Foundation through Award ANT-1103686). Computing resources were provided by the Climate Simulation Laboratory at NCAR's Computational and Information Systems Laboratory (CISL), sponsored by the National Science Foundation and other agencies. The CMIP5 simulations used in this research were enabled by CISL compute and storage resources. Bluefire, a 4064 processor IBM Power6 resource with a peak of 77 TeraFLOPS, provided more than 7.5 million computing hours, the GLADE highspeed disk resources provided 0.4 PetaBytes of dedicated disk, and the CISL 12-PB HPSS archive provided over 1 PetaByte of storage in support of this research project. In addition, this work used resources of the Oak Ridge Leadership Computing Facility, located in the National Center for Computational Sciences at Oak Ridge National Laboratory, which is supported by the Office of Science of the Department of Energy under Contract
DE-AC05-00OR22725. J. Ettema, W. J. van de Berg, J. Lenaerts, and X. Fettweiss are thanked for insightful discussions about the surface mass balance of the Greenland Ice Sheet.

\section{REFERENCES}

Bamber, J. L., R. L. Layberry, and S. Gogineni, 2001: A new ice thickness and bed data set for the Greenland Ice Sheet: 1. Measurement, data reduction, and errors. J. Geophys. Res., 106 (D24), 33 773-33 780.

Bougamont, M., J. Bamber, J. Ridley, R. Gladstone, W. Greuell, E. Hanna, A. Payne, and I. Rutt, 2007: Impact of model physics on estimating the surface mass balance of the Greenland Ice Sheet. Geophys. Res. Lett., 34, L17501, doi:10.1029/ 2007GL030700.

Box, J. E., X. Fettweis, J. C. Stroeve, M. Tedesco, D. K. Hall, and K. Steffen, 2012: Greenland Ice Sheet albedo feedback: Thermodynamics and atmospheric drivers. Cryosphere, 6, 821-839, doi:10.5194/tc-6-821-2012.

Ettema, J., M. van den Broeke, E. van Meijgaard, W. J. van de Berg, J. Bamber, J. Box, and R. Bales, 2009: Higher surface mass balance of the Greenland Ice Sheet revealed by highresolution climate modeling. Geophys. Res. Lett., 36, L12501, doi:10.1029/2009GL038110.

Fettweis, X., E. Hanna, H. Gallee, P. Huybrechts, and M. Erpicum, 2008: Estimation of the Greenland Ice Sheet surface mass balance for the 20th and 21st centuries. Cryosphere, 2, 117129.

, B. Franco, M. Tedesco, J. H. van Angelen, J. T. M. Lenaerts, M. R. van den Broeke, and H. Gallée, 2013: Estimating the Greenland Ice Sheet surface mass balance contribution to future sea level rise using the regional atmospheric climate model MAR. Cryosphere, 7, 469-489, doi:10.5194/tc-7-469-2013.

Gregory, J. M., and P. Huybrechts, 2006: Ice-sheet contributions to future sea-level change. Philos. Trans. Roy. Soc. London, 364A, 1709-1731, doi:10.1098/rsta.2006.1796.

Hurrell, J., and Coauthors, 2013: The Community Earth System Model: A framework for collaborative research. Bull. Amer. Meteor. Soc., 94, 1339-1360.

Jacobs, S. S., H. H. Helmer, C. S. M. Doake, A. Jenkins, and R. M. Frolich, 1992: Melting of ice shelves and the mass balance of Antarctica. J. Glaciol., 38, 375-387.

Lenaerts, J. T. M., M. R. van den Broeke, W. J. van de Berg, E. van Meijgaard, and P. Kuipers Munneke, 2012: A new, highresolution surface mass balance map of Antarctica (1979-2010) based on regional atmospheric climate modeling. Geophys. Res. Lett., 39, L04501, doi:10.1029/2011GL050713.

Lipscomb, W. H., and Coauthors, 2013: Implementation and initial evaluation of the Glimmer Community Ice Sheet Model in the Community Earth System Model. J. Climate, 26, 7352-7371.

Mikolajewicz, U., M. Groeger, E. Maier-Reimer, G. Schurgers, A. Winguth, and M. Vizcaíno, 2007: Long-term effects of anthropogenic $\mathrm{CO}_{2}$ emissions simulated with a complex Earth system model. Climate Dyn., 28, 599-633, doi:10.1007/ s00382-006-0204-y.

Mote, T. L., 2007: Greenland surface melt trends 1973-2007: Evidence of a large increase in 2007. Geophys. Res. Lett., 34, L22507, doi:10.1029/2007gl031976.

Ohmura, A., M. Wild, and L. Bengtsson, 1996: A possible change in mass balance of Greenland and Antarctic Ice Sheets in the coming century. J. Climate, 9, 2124-2135. 
Oleson, K., and Coauthors, 2010: Technical description of version 4.0 of the Community Land Model (CLM). National Center for Atmospheric Research Tech. Note NCAR/TN-478+STR, 257 pp.

Rae, J. G. L., and Coauthors, 2012: Greenland Ice Sheet surface mass balance: Evaluating simulations and making projections with regional climate models. Cryosphere, 6, 1275-1294, doi:10.5194/tc-6-1275-2012.

Reeh, N., 1991: Parameterization of melt rate and surface temperature on the Greenland Ice Sheet. Polarforschung, 59, 113128.

Ridley, J. K., P. Huybrechts, J. M. Gregory, and J. A. Lowe, 2005: Elimination of the Greenland Ice Sheet in a high $\mathrm{CO}_{2}$ climate. J. Climate, 18, 3409-3427.

Rignot, E., I. Velicogna, M. R. van den Broeke, A. Monaghan, and J. Lenaerts, 2011: Acceleration of the contribution of the Greenland and Antarctic Ice Sheets to sea level rise. Geophys. Res. Lett., 38, L05503, doi:10.1029/2011GL046583.

Robinson, A., R. Calov, and A. Ganopolski, 2012: Multistability and critical thresholds of the Greenland Ice Sheet. Nat. Climate Change, 2, 429-432, doi:10.1038/nclimate1449.

Shepherd, A., and Coauthors, 2012: A reconciled estimate of icesheet mass balance. Science, 338, 1183-1189.

Silva, T. A. M., G. R. Bigg, and K. W. Nicholls, 2006: Contribution of giant icebergs to the Southern Ocean freshwater flux. J. Geophys. Res., 111, C03004, doi:10.1029/2004JC002843.

Tedesco, M., 2007: Snowmelt detection over the Greenland Ice Sheet from SSM/I brightness temperature daily variations. Geophys. Res. Lett., 34, L02504, doi:10.1029/ $2006 \mathrm{gl} 1028466$.

— X. Fettweis, M. R. van den Broeke, R. S. W. van de Wal, C. J. P. P. Smeets, W. J. van de Berg, M. C. Serreze, and J. E. Box, 2011: The role of albedo and accumulation in the 2010 melting record in Greenland. Environ. Res. Lett., 6, 014005 , doi:10.1088/1748-9326/6/1/014005.

Thompson, S., and D. Pollard, 1997: Greenland and Antarctic mass balances for present and doubled atmospheric $\mathrm{CO}_{2}$ from the GENESIS version-2 global climate model. J. Climate, 10, 871900. van Angelen, J. H., J. T. M. Lenaerts, S. Lhermitte, X. Fettweis, P. Kuipers Munneke, M. R. van den Broeke, and E. van Meijgaard, 2012: Sensitivity of Greenland Ice Sheet surface mass balance to surface albedo parameterization: A study with a regional climate model. Cryosphere, 6, 1175-1186.

,,-- M. R. van den Broeke, X. Fettweis, and E. van Meijgaard, 2013: Rapid loss of firn pore space accelerates 21st century Greenland mass loss. Geophys. Res. Lett., 40, 2109-2113, doi:10.1002/grl.50490.

van den Broeke, M., P. Smeets, J. Ettema, C. van der Veen, R. van de Wal, and J. Oerlemans, 2008a: Partitioning of melt energy and meltwater fluxes in the ablation zone of the west Greenland Ice Sheet. Cryosphere, 2, 179-189.

,,,--- and P. K. Munneke, 2008b: Surface radiation balance in the ablation zone of the west Greenland Ice Sheet. J. Geophys. Res., 113, D13105, doi:10.1029/2007JD009283.

_, J. Bamber, J. Ettema, and E. Rignot, 2009: Partitioning recent Greenland mass loss. Science, 326, 984-986.

Vizcaíno, M., U. Mikolajewicz, M. Gröger, E. Maier-Reimer, G. Schurgers, and A. M. E. Winguth, 2008: Long-term ice sheet-climate interactions under anthropogenic greenhouse forcing simulated with a complex Earth system model. Climate Dyn., 31, 665-690.

,-- J. Jungclaus, and G. Schurgers, 2010: Climate modification by future ice sheet changes and consequences for ice sheet mass balance. Climate Dyn., 34, 301-324.

_ W. Lipscomb, W. Sacks, and M. van den Broeke, 2013: Greenland surface mass balance as simulated by the Community Earth System Model. Part I: Model evaluation and 1850-2005 results. J. Climate, 26, 7793-7812.

Wientjes, I. G. M., and H. Oerlemans, 2010: An explanation for the dark region in the western melt zone of the Greenland Ice Sheet. Cryosphere, 4, 261-268.

Wild, M., and A. Ohmura, 2000: Change in mass balance of polar ice sheets and sea level from high-resolution GCM simulations of greenhouse warming. Ann. Glaciol., 30, 197-203.

Zuo, Z., and J. Oerlemans, 1997: Contribution of glacier melt to sea level rise since AD 1865: A regionally differentiated calculation. Climate Dyn., 12, 835-845. 